\title{
ADMINISTRATIVE OBLIGATIONS OF VAT TAXPAYERS - SERBIA VERSUS EUROPEAN UNION
}

UDK / UDC: 336.225.61(497.11:4-67EU)

JEL klasifikacija / JEL classification: H20, H25

Pregledni rad / Review

Primljeno / Received: 5. studenog 2014. / November 5, 2014

Prihvaćeno za tisak / Accepted for publishing: 1. lipnja 2015. / June 1, 2015

\begin{abstract}
The tax administration of every tax form is a very important area of its successful operation. This is especially the case with taxes such as value added tax. Although it is important in the tax system of each country, as it greatly contributes to filling the country's budget, due to a number of specific features of its operation, it requires a well-timed legislation. In fact, it is a complex form of taxation which, if not set on the appropriate legal basis, can easily lead to high administrative costs for the state (i.e. its administrative entities) and taxpayers. There is a high risk of occurrence of tax evasion which, if occurs, leads to a set of problems in the tax system of a given state. This paper illuminates the difference in terms of demands that are placed in front of the taxpayers in two completely different tax systems. On the one hand, the Republic of Serbia, by its size and economic potential, has a relatively small economy, so it is necessary to set such tax regulations that will be "cheap" enough to meet the demands of the taxpayers, and which will ensure sufficient mass of fiscal revenues. On the other hand, the European Union has significantly developed tax legislation, which, at the same time, sets more complicated administrative requirements. Therefore, the recommendations for both analyzed areas will go in the direction of additional harmonization and simplification of legislation, as well as avoidance of cumbersome and inefficient administration. Finally, it is necessary to harmonize them (regulation and administration) with the amount of collected tax revenues.
\end{abstract}

Keywords: value added tax, tax administration, Serbia, the European Union 


\section{INTRODUCTION}

Value-added tax, a very generous form of consumption tax, has undoubted advantages over the earlier form of retail sales tax. These benefits are reflected in the fact that at every stage of the production and transportation chain only added value is taxable and thus the cumulative effect of tax is avoided. The added value, in fact, is the difference between the tax that is included in the selling price of its own products and (or) services and paid tax on the purchase of raw materials to manufacture these products.

Like any tax, value added tax requires adequate regulations and welltrained staff in terms of its administration. This form of sales tax, because of its specific characteristics, is very required tax, and without a proper legal framework that regulates the field of administration, as well as appropriate staff, would not achieve its efficiency in collecting public revenues.

In connection with the tax administration we should pay attention to the following: the volume of turnover of the taxpayers is the starting point for classifying them in terms of their inclusion in the system. Administrative obligations include obligations about VAT in connection with the registration, issuing invoices, record-keeping, filing tax returns, billing, paying of taxes, as well as regular reporting to the tax authorities and providing access to the books in order to control their business.

The following paper will give an overview of the theoretical postulates concerning administrative obligations of taxpayers, and make a comparative analysis of the laws of Serbia and the European Union which define this issue.

\section{REVIEW FROM THEORY}

Obligations of taxpayers represent an important area in the implementation of each tax form, especially tax such as VAT. The taxpayers, by carrying out its activities aimed to the sale of goods and (or) services that are subject to taxation by this tax directly contribute to achieving its primary objective. Since VAT is a complex tax form, this inevitably means that the administrative obligations imposed on taxpayers are greatly demanding to meet. They relate, at first, to the taxpayer registration, followed by a number of other obligations, such as invoicing, record-keeping, tax payments and regular reporting to the tax authorities. In this regard, this section will give a brief overview of the theoretical postulates on basis of which will be performed further analysis of individual specific legislation regarding tax administration. 


\subsection{The thresholds for registration}

One of the prerequisites for successful functioning of the VAT is setting minimum thresholds for registration of taxpayers. This question is more important because in many countries the majority of taxpayers are small and medium enterprises. Administratively we have to set such a minimal volume of traffic that should involve a greater number of VAT taxpayers in the system and, at the same time, to get minimized compliance costs of both the country's and the taxpayer's tax administration.

Here we are talking about the two situations. The first of them is setting quite low threshold, which would involve the greater number of taxpayers in the system. However, this requires a well-placed legal basis and this system works only in countries that have a stable tax system. Second situation would be setting up quite high thresholds. This means that the bulk of tax revenue comes from taxation of medium and large taxpayers. True, it would have lost some of the revenue that would be collected by taxing small taxpayers, but this loss would be lower than the administrative costs that would be incurred if the same is found in the system. This situation favors countries with underdeveloped tax regulations.

Both situations have advantages and disadvantages. Since this is a completely opposite situation (low thresholds favor developed, high thresholds undeveloped or less developed tax systems), this means that we should make such a compromise that includes more taxpayers into the system, while the administrative costs of country and taxpayers themselves are minimized. Determining the optimum in terms of the amount of these costs would be made by taking into account a range of factors affecting the financial burden on taxpayers, with the same due to the fulfillment of administrative obligations. The same applies to the tax administration of the country. Regulations should be positioned so as to avoid the inefficiencies that would be caused by their inadequate explanations. This question is not simple, and the solution of this problem would be left to the experts in this field. The ideal situation, where all taxpayers would be included in the system, based on the aforementioned reasons, it is not feasible. The main reason for exclusion of small taxpayers should be the starting point in the enactment of the legislation.

Because all of these, we can not set a universal model. According to the author of this paper, one of the possible approaches would be to set up a combined approach depending on the situation in a particular country in a way that make the assessment of the opportunity costs that would cause a (non)inclusion of small taxpayers in the system. Further, this means that developed countries do not need to set so low thresholds, to include all taxpayers in the system, while developing countries should set up higher thresholds, but not so high, because, otherwise, they would lose much of the tax revenue due to noninclusion of all small taxpayers in the system. You should go to such arrangement in which the threshold for inclusion as (a part) of small taxpayers took a yearly volume (planned or actual) of turnover of small entities through which, by special 
legislation, they would be subject to taxation. (Bird and Gendron,2007, pp. 115120)

\subsection{Registration of taxpayers}

After elaboration of theoretical principles of thresholds for registration, in this section it will be given an overview of the process of registration, i.e. requirements that have to be met in order to be considered a legal entity taxpayer.

In a case that entity undertakes certain activities subject to VAT, and meets the requirement for the realized volume of traffic, it should be registered for VAT, i.e. it must be in the system. Of course, like all the other conditions, these conditions must be sufficient administrative "cheap" to the taxpayers, and enough "expensive" to prevent tax evasion, which could arise from the establishing of shell companies whose main goal would be to achieve financial gain from unjustified high tax credits and refunds.

If the business entities choose to register (or if registration is required by law) for VAT, they are required to, in order to do legitimate business, keep, at least, a record of incoming and outgoing (i.e. received and issued) invoices, in order to determine height input and output tax.

In a well-organized tax systems, companies that have not registered for VAT, which operate with a registered VAT taxpayers, have an incentive to register for VAT, because it would be able to claim input tax credit. The taxpayers who are not registered for VAT have no administrative obligations that have to be fulfilled by registered VAT taxpayers, but, at the same time, do not have any rights to acquire if they are in the system. Since, by definition, the tax is based on the credit-invoice method, this means that every taxpayer is entitled to refund of input VAT, which, in the case of unregistered taxpayers, lacking. However, if the companies meet the legal requirements for registration, but they refuse to register, it shall be deemed that they have committed an offense, and they will have to pay the appropriate penalties prescribed by law. (Bird and Gendron,2007, pp. 166-167)

\subsection{Filling in the application and payment of VAT}

The taxpayers, in most cases, have to submit the tax application within one month from the date when the tax period is completed. However, this time limit varies depending on the size of the taxpayer, so that some taxpayers may submit applications for a longer period of time, for example, quarterly, semiannually or annually. If in the predicted time tax application is not filled, it shall be deemed that taxpayer have committed a tax offense and, therefore, will be invoiced the penalties imposed by law. 
About the application, it is important to note that if the tax was overpaid, the taxpayer may claim a refund for overpaid tax, or the same can be used as a tax credit in the next tax period(s). If taxpayer opts for a tax credit, then, in the next application, the tax liability will be reduced by the excess of the tax from the previous period. However, if he chooses option to refund, i.e. return, then, after the submitted application, the country is obliged to return tax in the shortest possible time. If the country does not do so in time, the amount is increased by the accrued interest that is determined by law.

About application, as well as the payment of VAT, it is important to note that, since VAT operates on credit-invoice method (this was mentioned earlier in this paper), all payments must be in accordance with the returns. In the case of requesting the refund, if tax application for tax payment is not made timely by the taxpayer, then, in addition to net tax liability, statutory interest is charged. (Bird and Gendron,2007, pp. 167-168)

\subsection{Audit}

The audit is one of the most important aspects in the design of any VAT system, and with a right it can be called its core. Its importance stems from the functioning of the VAT system, and it is, as has been repeatedly pointed out, the credit-invoice method. Anyway, if a particular company consistently shows lower output tax, therefore, it is more entitled to claim an input tax credit; it may be signal for tax administration to pay attention on a particular company, because it can happen that such company intends to evade taxes. In this regard, it is necessary to set certain criteria to serve as a benchmark in determining the (in) feasibility of the request for approval of tax credits and (or) tax refund.

On the other hand, the audit aims to ensure compliance with the submission of tax applications and the payment of taxes. In both cases, if there are irregularities, the audit should be placed so that the penalties that have to be paid are intended to encourage taxpayers to avoid these offenses. Further, this means that the penalties should be neither too low, because in this case, creating unnecessary costs of tax administration, nor too high, because then the taxpayers would not be able to financially bear them. (Bird and Gendron,2007, pp. 169-172)

\subsection{Enforcement}

Unpaid tax liabilities are surprisingly important aspect of VAT. This is particularly important in cases where the bulk of these debts is comprised from a small number, as a rule, medium and large businesses. In fact, it should not be a lot of these debts, especially with regard to imports, since; in this case, the tax liabilities are paid before the goods are released for retail sale. If this treatment proves to be too "harsh" for many exporters, it could be thought about limited "deferral" scheme for a small number of exporters, who would be classified in a 
particular category. If penalties are introduced, they must be implemented rigorously, at once and without exception. If they are charged but unpaid, it must be taken other legal actions. As mentioned earlier, these penalties must be neither too low nor too high.

Failure to comply with tax regulations can be seen in such tax evasion that most directly affects the tax revenues of the country. This is particularly evident if one takes into account that the taxpayers themselves exercise control (or, as some authors suggest, self-assessment) of the tax, because of the operation of VAT (that is, as has been repeatedly pointed out, the credit- invoice method). (Bird and Gendron,2007, pp. 172-175)

\section{OBLIGATIONS OF VAT TAXPAYERS IN REPUBLIC OF SERBIA}

After a large number of attempts of its introduction, the value added tax in Serbia was finally introduced in 2004, starting the application from 1.1.2005. year. To date, there were numerous of amendments to this Act. This section will provide an overview of the main changes that are related to the registration of taxpayers, as well as obligations that are acquired on the basis of the registration.

Before proceeding to a detailed analysis of the obligations of taxpayers, it will be briefly given an overview of the size of the taxpayers in terms of regulations governing the issue of value added tax in Serbia.

Value added tax legislation, pursuant to the turnover of the goods and serrvices that companies perform, define the taxpayers as small, medium and large taxpayers.

The latest amendments to the Law on Value Added Tax of the Republic of Serbia has changed the definition of a small taxpayers. This is done by increasing the threshold for mandatory registration from the previous 4000000 dinars (50 022,51 Euros) to 8000000 dinars (70 716,54 Euros) and with no threshold for voluntary registration, which was amounted to 2000000 dinars (25 011,26 Euros). By canceling the threshold for voluntary registration, there is given an opportunity to all business entities to choose whether they want to register for VAT or not. The amended Article 33 of the Law on Value Added Tax of the Republic of Serbia now defines small taxpayers as persons who supply goods and services in the territory of the Republic of Serbia and / or abroad, and whose total turnover of goods and services in the previous 12 months, is not larger than 8000000 dinars (70 716,54 Euros) or who on the commencement of the activity estimates that total turnover over the next 12 months will not achieve 8000000 (or more) dinars (70 716,54 Euros). In doing so, total a turnover includes taxable sales and exempt sales with the right to deduct input VAT, except transport equipment and facilities. 
What is unfavorable treatment of legal entities as micro-enterprise is the fact that because of non-inclusion in the VAT system small taxpayer has no obligations that have registered taxpayers, but it also doesn't have rights granted to the entities involved in the VAT system. This particularly refers to the inability to deduct input VAT and therefore registered taxpayers are more oriented to the collaboration with other registered taxpayers, rather than cooperation with small taxpayers. That's why the legislature provided the possibility to include companies with a total turnover volume of less than 8000000 dinars $(70716,54$ Euros) in the VAT system. However, it should be noted that if these companies still opt for VAT registration, the obligation to pay tax lasts at least two years, and after that it is possible to apply for removal from the register of VAT taxpayers.

In the rest of paper each of the obligations of taxpayers will be covered more detailed.

\subsection{The registration and deregistration of taxpayers}

According to the amended Article 38 of the Law on Value Added Tax of the Republic of Serbia, all entities that in the past 12 months have achieved a total turnover of more than 8000000 dinars (70 716,54 Euros), shall not later than the expiry of the first deadline for the submission of periodic tax returns submit the registration form to the competent tax authority. This applies to small taxpayers and farmers who opted to pay VAT.

Registration form is submitted on the EPPDV. This form contains the following information:

- the identification information of the taxpayer listed tax identification number (TIN-PIB) for legal entities (or unique personal identification number of citizens-JMBG for farmers), the registration number of the legal entity or actions, firm in the full and abbreviated form, name of authorized person as well as data on the seat or place of residence

- the data on the performance of activities in the future (these data are given in a code and name of business-maximum three activities), as well as the percentage share of each sector in total business, the start date of the activity, and the amount of the actual and the estimated total turnover in the preceding and following 12 months in dinars, without decimals

- the information on the bank account which includes the residence of bank, the bank name and account number

- the data of connected persons (if any of them exists) for legal entities, their TIN-PIB, the fact that it comes to a foreign or domestic entity and the percentage of its (or their) participation, whereas natural persons provide a unique personal identification number and the percentage of participation. 
After registration application is filed, the tax authority shall issue a certificate of VAT registration. This certificate is issued on the PEPDV and include the name, location and TIN of the taxpayer, and the date when he made records for VAT.

Following the completion of the registration procedure, the taxpayer is obliged to write tax identification number on all documents.

About tax identification number, it should be noted that this number contains 9 digits, of which the first 8 provides the number of registration of the taxpayer, and one digit is a control number. <www.poreskauprava. gov.rs/sr/nerezidenti/pregled-propisa/pravilnici/127/pravilnik-o-poreskom-identifi kacionom-broju.html $>$ [10 May 2013]

In addition to records of taxpayers, equally important question is deletion of taxpayers from tax records. According to the Law relating to deletion of the taxpayers a large number of changes are made. These changes will be discussed in more detail below.

The new Article 38a and Article 51 of the Law provides for the following procedure of deletion:

At the request of the taxpayer who in the previous 12 months was not achieved total turnover of more than 8000000 dinars (70 716,54 Euros), for the termination of the obligation to pay VAT, the tax authority conducts the clearing process and issue a certificate of deregistration for VAT. The request must contain information about the date of termination of VAT activities.

What is important to note is the following: before removal from the register of companies, VAT taxpayer who ceases to perform the activities required that no later than 15 days before submitting the application for removal from the register of companies submit a request for removal from the register of VAT the taxpayers to the competent tax authority. On the basis of the request, the competent tax authority shall conduct deletion, but it also has the obligation to issue a certificate of deletion, otherwise deletion will not be valid. This certificate is issued on the PBPDV form and contains the same information as the form PEPDV, but in addition to them, the date when the removal from the register for VAT occurred.

It is necessary to distinguish two cases. VAT taxpayers which continue to conduct business, and who submitted a claim for deletion from the register of VAT taxpayers, pay the tax within 15 days of filing tax returns, and taxpayers who cease to do business pay tax to the date of application for removal from the register of business entities.

During deciding about submitting a request for removal from the register of VAT taxpayers, it is important to pay attention to the following. Previous Article 39, which regulates the clearing taxpayers who have not reached the threshold for voluntary registration, so what is the deletion of the same carried out 
ex officio, is deleted, and Article 40, which sets out the obligations of VAT payers who filed for removal from the tax records, is amended. According to this Article (Article 40), the taxpayer is required to: 1) draw up an inventory of assets, including equipment, facilities for the performance of activities and investments in their own and other facilities, as well as advance payments pursuant to which he was entitled to deduct input tax and draw on the census list, 2) correct the input tax deduction for equipment, facilities for the performance of activities and investments in facilities and 3) determine the amount of the input tax on goods, except for equipment, facilities and investment in facilities, and prepayments. The obligation of the inventory and making inventory lists is related to purchase of the goods when the VAT taxpayer have the right to deduct input tax, but purchases of the goods when the taxpayer was not entitled to deduct input tax are not included in this list. According to the provisions of paragraph 2 of this Article, the amount of the corrected input tax deduction for equipment, facilities and investment in facilities, as well as the amount of the tax deduction for all other assets and prepayments pursuant to which he was entitled to deduct input tax payer is treated as a tax due and payable by the prescribed period. With the tax return is he has to submit the inventory list.

About deletion of taxpayers who supply tax-exempted goods without the right to a tax deduction, it is important to emphasize that the circulation of such goods are not included in the total turnover.

Based on the above we can conclude the following. The procedure for deleting of the taxpayers will be done exclusively on his request. This request is submitted on the ZBPDV form and contain the basis on which the deletion should be done. This ground may be the termination of the obligation to pay taxes or cessation of activities. Further, this means that due to the abolition of the previous threshold for voluntary registration of 2000000 dinars (25 011,26 Euros), as well as increasing the threshold when taxpayers must be recorded in the system, a large number of taxpayers file a request for removal from the register.

It is important to note that the existing form ZBPDV does not allow the application of Article 38a para. 3, which provides that the application must contain information about the date of termination of tax activities, and, in this regard, it is expected its review on the matter. <http://www.karanovicnikolic.com/2012/10/10/srbijaporezi-bilten-oktobar-2012/?lang=sr $>$ [10 February 2013]

Of course, the taxpayer is required to report any change of information relevant to its operations in the VAT system, and the same is done on the form IEPDV.

The next two tables show thresholds for Republic of Serbia, as well as, thresholds in EU countries. 
Table 1

Thresholds for registration in Republic of Serbia

\begin{tabular}{|l|l|l|}
\hline & In dinars & In Euros \\
\hline $\begin{array}{l}\text { Previous threshold for } \\
\text { voluntary registration }\end{array}$ & 2000000 & 25011,26 \\
\hline $\begin{array}{l}\text { Old threshold for } \\
\text { obligatory registration }\end{array}$ & 4000000 & 50022,51 \\
\hline $\begin{array}{l}\text { New threshold for } \\
\text { obligatory registration }\end{array}$ & 8000000 & 70716,54 \\
\hline
\end{tabular}

Note: calculations for amounts in Euros were made by using yearly average exchange rates

Table 2

Thresholds for registration i EU countries

ANNEX 1: THRESHOLDS (MARCH 2012)

\begin{tabular}{|c|c|c|c|c|c|c|}
\hline \multirow[t]{2}{*}{ Member State } & \multicolumn{2}{|c|}{$\begin{array}{l}\text { Threshold for application of the special scheme } \\
\text { for acquisitions by tarable persons not entitled to } \\
\text { deduct input tax and by non-tarable legal } \\
\text { persons }\end{array}$} & \multicolumn{2}{|c|}{$\begin{array}{l}\text { Threshold for application of the special } \\
\text { scheme for distance selling }{ }^{2}\end{array}$} & \multicolumn{2}{|c|}{ Exemption for small enterprises ${ }^{3}$} \\
\hline & National currency & Euro equivalent & National currency & Euro equivalent & National currency & Euro equivalent \\
\hline Belgium & $€ 11.200$ & & $€ 35.000$ & - & $€ 5.580$ & \\
\hline Bulgaria & $20.000 \mathrm{BGN}$ & 10.226 & $70.000 \mathrm{BGN}$ & 35.791 & $50.000 \mathrm{BGN}$ & 25.565 \\
\hline Czech Republic & $326.000 \mathrm{CZK}$ & 13.318 & $1.140 .000 \mathrm{CZK}$ & 46.570 & $1.000 .000 \mathrm{CZK}$ & 40.851 \\
\hline Denmark & $80.000 \mathrm{DKK}$ & 10.730 & $280.000 \mathrm{DKK}$ & 37.557 & $50.000 \mathrm{DKK}$ & 6.707 \\
\hline Germany & $€ 12.500$ & & $€ 100.000$ & - & $€ 17.500$ & \\
\hline Estonia & $€ 10.226$ & & €35.151 & & $€ 15.978$ & \\
\hline Ireland & $\epsilon 41.000$ & - & 635.000 & - & $€ 75.000$ or $€ 37.500$ & \\
\hline Greece & $€ 10.000$ & - & $€ 35.000$ & - & $€ 10.000$ or $€ 5.000$ & \\
\hline Spain & $€ 10.000$ & - & $\epsilon 35.000$ & - & None & None \\
\hline France & $€ 10.000$ & - & $€ 100.000$ & - & $€ 81.500$ or $€ 32.600$ & \\
\hline Italy & $€ 10.000$ & - & $€ 35.000$ & - & $€ 30.000$ & \\
\hline Cyprus & $€ 10.251$ & - & $€ 35.000$ & - & $€ 15.600$ & \\
\hline Latvia & $7.000 \mathrm{LVL}$ & 9.932 & $24.000 \mathrm{LVL}$ & 34.052 & $35.000 \mathrm{LVL}$ & 49.659 \\
\hline Lithuania & $35.000 \mathrm{LTL}$ & 10.137 & $125.000 \mathrm{LTL}$ & 36.203 & 100.000 LTL & 28.962 \\
\hline Luxembourg & $€ 10.000$ & - & $€ 100.000$ & - & $€ 10.000$ & \\
\hline Hungary & $2.500 .000 \mathrm{HUF}$ & 9.164 & $8.800 .000 \mathrm{HUF}$ & 32.257 & $5.000 .000 \mathrm{HUF}$ & 18.328 \\
\hline Malta & $€ 10.000$ & - & $€ 35.000$ & - & $\begin{array}{r}€ 35.000 \text { or } € 24.000 \text { or } \\
€ 14.000 \\
\end{array}$ & \\
\hline Netherlands & $\epsilon 10.000$ & - & $€ 100.000$ & - & None & None \\
\hline Austria & $€ 11.000$ & - & $€ 35.000$ & - & $\epsilon 30.000$ & \\
\hline Poland & $50.000 \mathrm{PLN}$ & 12.592 & $160.000 \mathrm{PLN}$ & 40.293 & 150.000 PLN & 37.774 \\
\hline Portugal & $€ 10.000$ & - & $€ 35.000$ & - & $€ 10.000$ or $€ 12.500$ & \\
\hline Romania & 34.000 RON & 8.071 & $118.000 \mathrm{RON}$ & 28.012 & 119.000 RON & 28.249 \\
\hline Slovenia & $€ 10.000$ & - & $€ 35.000$ & - & $€ 25.000$ & \\
\hline Slovakia & $€ 13.941,45$ & - & $€ 35.000$ & - & $€ 49.790$ & 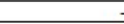 \\
\hline Finland & $€ 10.000$ & & $€ 35.000$ & - & $€ 8.500$ & \\
\hline Sweden & $90.000 \mathrm{SEK}$ & 10.190 & 320.000 SEK & 36.232 & None & None \\
\hline United Kingdom & $70.000 \mathrm{GBP}$ & 81.843 & 70.000 GBP & 81.843 & $70000 \mathrm{GBP}$ & 81.843 \\
\hline
\end{tabular}

See Article 3(2)(a) of Directive 2006/112/EC, as amended

See Article 34 of Directive $2006 / 112 \mathrm{EC}$, as amended

See Articles 284 to 287 of Directive $2006 / 112 / \mathrm{EC}$, as amended. This scheme is reserved for taxable persons established within the territory of the country. 


\subsection{Invoicing}

After the registration in the VAT system, the taxpayer, as it was previously mentioned, is required, in addition to details of the name and address, as well as the invoice number, to provide his tax identification number (TIN) on each invoice he issues. Of course, in addition to its TIN, he is required to provide information about the name and domicile of the customer, as well as the customer's VAT number. Other information on the invoice identifies the type and quantity of goods, and the date when their traffic is made. New information is a statement of the amount of the base to which it applies certain tax rate, information about height tax rate (in percent) and information of the amount of output tax. Also, it should be specified a note on the provisions of the VAT on which VAT is not included, as well as a note about applying billing system on the goods and services.

The invoice has this appearance when transaction about buying and selling goods is made between the two registered taxpayers. However, if supply of goods and services is made between the registered taxpayer and the person who is not in the system, then the information of the buyer have the name and address of the person, and, instead of a TIN, a unique personal number of citizen.

One innovation in the new rules about issuing invoices is that the invoice must be issued for each supply of goods and services, no matter who is the recipients of the same, unlike the old rules, where invoice have to be issued only if the supply of goods and service was made between the registered taxpayers.

A list of innovations does not end here. In fact, there are several cases in which there are no obligation to issue an invoice. These cases are:

- In case of the supply of goods and services to persons who are not liable to pay tax, except in case of individuals who are entitled to a refund of this tax;

- In case of the supply of goods and services that are tax-exempted without giving the right to claim a credit for input tax;

- In case of the supply of goods and services free of charge and

- In case of goods and services that are not subject to taxation.

Also, neither invoice should contain all data; these data vary depending on the type of traffic for which the invoice is issued.

This invoice is published in at least two copies, with one retained by the issuer of invoice, and the rest is given to the recipient.

If the income of tax is higher than income the taxpayer owes, he shall pay such VAT as it is shown, until the correct amount of tax is not shown on the new invoice. This correction is made in the tax period in which the invoice was issued with the corrected amount of tax. If an invoice is issued by a person who is not subject to VAT or who did not make supply of the goods and services, he 
owes tax reported. <http://www.karanovic-nikolic.com/2012/10/10/srbijaporezibilten-oktobar-2012/?lang=sr $>$ [5 April 2013]

At this point it would be interesting to mention the sale of goods through the retail, i.e. for cash. In this case, the invoice is typed through the cash register, and under the TIN number is shown IBFM number, while the tax rate and the tax amount is listed under the description of item. These data is indicated like the $\mathrm{S}$ $(\mathrm{X}), \mathrm{P}(\mathrm{X}), \mathrm{PT}$, where $(\mathrm{X})$ is the letter that is added as an identification number, and PT is the label for the total amount of taxes. The final price is denoted by $\mathrm{E}$ $(\mathrm{X})$ and ET (X has the same meaning as in previous markings, and ET is the label for the total, i.e. gross amount of goods). At the end of the invoice is BI number, which is in fact, a number of fiscal receipts. (http://www.paragraf.rs/propisi/pravilnik_o_konturi_i_bitmapi_fiskalnog_loga_iz gledu_fiskalnih_dokumenata_i_znacenju_pojedinih_podataka_sadrzanih_u_fiskal nim_dokumentima.html)

\subsection{The obligation to record-keeping}

As discussed earlier in this paper, all VAT taxpayers in order to do legitimate business should at least keep records of incoming and outgoing invoices, in order to more successfully exert control by the tax authorities. These records and documents based on which the records are kept, shall be kept until the expiration of the period of limitation for assessment and collection of taxes (which, according to the amended Article 47, is 5 years long), i.e. a minimum of 10 years after the calendar year of the first use of facilities and completion of investment in facilities for activities.

\subsection{The tax period, filing, billing and VAT payment}

Amended Article 48 of the Law on value added tax defined that tax period is calendar month for taxpayers who start for the first time VAT activity in the current calendar year, as well as for taxpayers who in the past 12 months achieved a total turnover of more than 50 million dinars, i.e. 441 978, 40 Euros (or who estimates that in the next 12 months achieves volume of mentioned traffic) and who applies billing system. Also, this Article provides that the tax period is calendar quarter for those taxpayers who in the past year earned (or who estimate that in the next year will achieve) the volume of traffic less than 50 million dinars (441 978, 40 Euros), except for taxpayers who apply billing system. In addition to these cases in terms of the tax period, it is important to emphasize that for the tax debtor who is not a VAT payer; the tax period is the calendar month.

Article 49 of the Law stipulates the obligation of the tax base. The taxpayer is required to compute the tax for the tax period in which the tax liability arose, and the taxpayer is, at the same time, tax debtor. In the calculation of this 
tax is considered adjustments arising on the basis of changes of the tax base, as well as adjustments in the case of showing a higher amount of tax than he owes. Also, the taxpayer is entitled to deduct his tax liability for the amount of the input tax, whereby the calculation are taken and adjustments resulting from the changes to the tax base, as well as the correction of input tax for equipment and facilities to carry out the activity.

Also, the deadlines for filing tax application (Article 50) have introduced certain changes. For the taxpayer who the tax period is the calendar month the deadline for filing is 15 days after the expiration of the tax period, and for taxpayers who report filed quarterly this deadline is 20 days after the expiration of the tax period. Tax debtors who are not taxpayers submit an application within 10 days after the expiration of the tax period, and the taxpayers who will be erased from the register of VAT fill application on the date of the filing request for deletion. In this case the tax return is filed for the period from the date of the tax period in which the request for deletion has been made to the date of termination of VAT activities. <http://www.karanovic-nikolic.com/2012 /10/10/srbijaporezi-bilten-oktobar-2012/?lang=sr $>$ [5 March 2013]

What is important to emphasize is that the taxpayer filed tax return regardless of whether the tax period is subject to tax.

Tax return is filed on form PPPDV. In this form, in addition to data of the taxpayer (TIN-PIB and the name and address), and the period, for which the application is filed, state the following information:

- The data on the supply of goods and services referred to the total supply of goods and services that are exempted from VAT, with and without the right to deduct input tax and goods and services where the general and special rate is applied. It should be noted that in the first two items stated fee without VAT, while in the other two, in addition to this amount, according to the amount of VAT. These amounts are listed in dinars, without decimals.

- The amount of the input tax states previous tax paid on importation, the VAT compensation paid to farmers, while as the next paragraph states the amount of the previous withholding tax of the two amounts. These amounts are also listed in separate columns and as compensation amounts without taxes and the amount of the tax, in dinars, without decimals.

Of course, at the end, there is the net tax liability, which is obtained as the difference between the sums of total tax liability and the total of the input tax on those grounds. 


\subsection{Control and submission of reports}

About controlling and submitting reports to the tax administration, it is necessary to emphasize the following:

The Republic of Serbia still does not have sufficiently developed information system that would allow the direct control of the taxpayer's business electronically, like it is the case with the EU. This means that in practice is still carried out field control, since all documentation is in printed form. Of course, the legislation provides that the taxpayer has obligation to, at certain intervals, submit reports to the tax authorities, and to notify tax authorities about any changes that could have an impact on his treatment in the tax system (one of these changes is, for example, changes in ownership or organizational structure), which is made on the prescribed forms (in this case in the form IEPDV, where is necessary to round up what changes occurred).

Another important thing regarding the submission of a report and, in general, the records, are compliance costs. The introduction of electronic control and reporting systems significantly reduce these costs. Each release of the court by the tax inspectors, the volume of documentation (forms) that must be acquired and only its preservation requires certain costs that in the long term can be a great burden on the taxpayer.

\section{OBLIGATIONS OF TAXPAYERS OF VALUE ADDED TAX IN THE EUROPEAN UNION}

Unlike the Republic of Serbia, value-added tax as a form of consumption tax is already in force in the European Union for more than 40 years. The VAT in EU was introduced by adopting the Directive 67/227/EEC of 11.4.1967. years (although before its introduction existed certain forms of consumption tax similar to VAT). The next stage in the development of this tax is adopting the Directive 77/388/EEC of 17.5.1977. year (this directive is known as the Sixth Directive), which has harmonized rules that must be applied by all Member States. Over time, due to the necessary amendments, there was need for the adoption of a new directive that would include all of the following amendments, which was done by adopting the Directive 2006/112/EC of 28.11.2006. year and in this in form it functions today. In this Directive the obligations of taxpayers are much more organized, but the rules that govern them are still complementary and altered by many amendments. In the rest of paper each of these obligations of the taxpayer will be covered more detailed, as it has been done in the case of the Republic of Serbia. 


\subsection{Thresholds}

Before going on to analyze the thresholds for registration of value added tax taxpayers in the European Union, the following should be noted: In addition to classical transactions of selling goods and services (i.e., internal and external trade), one of the specific activities is distance selling. Since each form of these transactions has specifically prescribed threshold(s), and the most characteristic form of distance selling, we will first perform its detailed elaboration.

Distance selling in the EU occurs when a supplier in one EU country sells goods to a person who is not registered for VAT, which residence is in another Member State, and where the supplier is responsible for delivery of the goods. It involves the sale by mail, telephone, and purchase classic goods ordered over the internet.

Buyers of goods purchased through distance selling are mostly individuals, but they can also be small unregistered businesses, businesses that are completely excluded from the system, charities and government bodies.

In an arrangement of distance selling, selling to customers who are not registered for VAT, which is located in other Member States, are subject to VAT in the Member State where the supplier is established, provided that the thresholds for this activity prescribed by the Member State of the customer are not violated. Where sales exceed these thresholds in any member state, the supplier must register an account for VAT in that Member State.

If the foreign supplier is obliged to register for VAT in another Member State, as the value of its annual distance sales to customers in the same state exceeds or is likely to exceed the registration threshold set out by that Member State it must submit a registration form. Then he acquires all the rights and obligations under the law. <http://www.revenue.ie/en/tax/vat/leaflets/distancesales-eu.html $>$ [7 July 2013]

Article 34 of Directive 2006/112/EC lays down detailed requirements for the registering of taxpayers about distance selling. If taxpayer perform distance selling, and if value of the delivery in another Member State, during a period of in one calendar year, does not exceed 100,000 Euros (this value doesn't include VAT), there are no obligation to register. However, Member States may set a threshold of 35000 Euros, if it assess that the threshold of 100,000 Euros might cause serious distortion of competition. If this occurs, Member States must inform the competent national authorities of the country where the dispatch of goods begins, after which the European Commission will present to the Council of Europe report on setting up a special threshold of 35000 Euros, followed by specific proposals, if they become needs. (European Commission, 2006) 


\subsection{Registration and deregistration of taxpayers}

As the dominant model of value added tax, EU regulations governing the registration of taxpayers require that any person who performs an activity which is subject to taxation by value added tax is required to register for VAT. However, the specificity of the Union in respect of the registration of taxpayers is the existence of multiple registration forms, which are in scope quite demanding. It stipulates that one form is used for registration of taxpayers pursuing the activity of distance selling, while the second form is used for the registration of taxpayers who carry out all other ways of selling goods and services. Of course, the rule is: legal person may choose to make voluntary registration; otherwise, if his turnover reaches threshold for obligatory registration, he must submit registration form. Once completed and submitted the application for registration (form VAT 1 or form VAT 1a or form VAT 2), if it is determined that the applicant meets all the requirements for registration, then a certificate of registration is issued (form VAT 1C). After successful registration tax identification number is granted. This number consists two parts. The first part consists of two alpha characters; it is abbreviation of the Member State; the second part is a combination of alphanumeric or numeric characters; for each country specific rules assigning these labels are provided. For example, German format TIN does the prefix DE, followed by 9 digits. $<$ http://ec.europa.eu/taxation_customs/taxation/vat/traders/vat_number/\#backgrou nd $>$ [6 June 2013]

However, if there is a change of data relevant to the proper functioning of the taxpayer in VAT system, the taxpayer is required to report any change of filling out a form VAT 484. These changes include a request for the transfer of a TIN (tax identification number), or a change in ownership structure.

If, for any reason, the taxpayer chooses to file a request for removal from the system, it does so by filing form VAT 7, stating the basis of submission.

\subsection{Invoicing}

Article 220 of Directive 2006/112/EC provides that any person who is engaged in trade of goods and services that are subject to taxation by value added tax, has obligation to issue an invoice for delivered goods and services. This obligation must be met regardless of whether the goods are sold (or services provided) to another taxpayer or to a person who is not a taxpayer (or that is completely exempted from tax). Since all taxpayers are in a unique tax information system, the Member State in whose territory the trade of goods and services by a taxpayer who is a resident of another Member State, it may look the same, based on all invoices, prepare a summary invoice. This invoice can be made both on the basis of output invoices and at the input invoices, provided that the report is based on the latter may be made if there is an agreement between both sides, and if the same procedure, relating to acceptance of each invoice 
issued by other taxpayers who supply goods or services, exists and is applied by both sides. This procedure must be unique and valid in all Member States in which the taxpayer has an office or business unit.

About elements of the invoice, it's provided that the account must include the following: 1) the date of issue, 2) the serial number, which is based on one or more series of invoices, which is unique to each invoice, 3) VAT identification number of taxpayer, or vendor, 4) VAT identification number of customer, 5) the full name and address of the taxpayers who are the participants in the sale and purchase transaction, 6) the nature and quantity of the goods in the contract, 7) the date when the goods or the services are performed, 8) the taxable amount per appropriate tax rate (the amount of tax), or a statement of exemption, the unit price exclusive of tax, discounts or rebates if they are not included in the unit price of goods, 9) the VAT rate applied, 10) the tax amount payable, and other elements (these elements are specified in Article 226 of the Directive). (European Commission, 2006)

Among other provisions relating to invoicing, it is important that Member States shall not require invoices to be signed, that amounts which appear on the invoice may be expressed in any currency, provided that such currency is the currency of the Member State in the territory of buying and selling is done, with the currency must be subject to the mechanism of conversion of the official currency of the European Union.

As far as the control mechanism, Member States may require that invoices in respect of supplies of goods and services in their territory and invoices received by taxable persons established in their territory to be translated into their national languages.

With regard to the form in which the invoice is issued, it is important to note that the invoice can be issued both in paper and in electronic form. If the invoice is issued in electronic form, there must be a mechanism to determine its authenticity and integrity of the data on it. Also, if necessary, Member States may require a digital signature that is based on a specific certificate that is issued to a legal person, ie. taxpayer. However, unless these obligations, the Member States may not impose any additional requirements with regard to invoices issued electronically. But, Member States may lay down specific conditions for invoices that are issued electronically in respect of goods or services supplied in their territory from a country with which no legal instrument exists relating to mutual assistance for all Member States. If a group of invoices is sent electronically to the same recipient, the more common elements for all invoices can be listed only once. 


\subsection{Record-keeping}

Every taxpayer shall keep the register of goods that are shipped by (or on behalf of) the taxpayer in another Member State, which is different from the Member State from which the goods are dispatched, for the purposes of checking such transactions. Also, this obligation applies to the storage of invoices to identify the goods that are shipped by (or on behalf of ) the taxpayer from another Member State. The taxpayer is also obligated to keep all copies of the invoices, issued by him, by his customer or by a third person who issued them in his name, and those that he received. These invoices must be available to tax authorities whenever there is a need for their control. This control system, which will be discussed later, provides online access to each individual invoice. The authenticity of origin and integrity of the contents of these invoices, as well as their readability, must be guaranteed throughout the prescribed period of their retention. In addition, each Member State determines the length of the storage period for issued and received invoices. For this to be complied with, Member States shall provide the obligation to keep these invoices in their original form. These obligations relate to invoices received by both registered as well as unregistered taxpayers. If the taxpayer keeps invoices in a Member State other than that in which its seat, the tax authorities of the country where taxpayer is established must have access to those invoices electronically, and the possibility of their direct use within the limits stated in the Member State in which the taxpayer has headquarters, to the extent they are needed for control purposes. (European Commission, 2006)

\subsection{Control}

About control mechanism, it should be noted that the EU applies a specific control system called VIES (VAT Information Exchange System). It was introduced after the introduction of the single market. The introduction of this system reduced administrative costs incurred by customs clearance of goods crossing the borders between individual member states.

The system works on following way. If there is a trade between the Member States, goods are exempted from tax in the country from which the goods are shipped, but they are taxed in the country of receipt of goods. Thus, a taxpayer who makes such delivery must be able to quickly and easily check if the consignee in another Member State is registered taxpayer and whether the person possesses a valid VAT number. To this end, each member country maintains its own database of VAT registration data of companies established in that Member State. These include the VAT identification number of taxpayers, date when invoice is issued, the name and address of the legal entity and expiration date of a VAT identification number, if that information exists.

In fact, the primary purpose of such information system is to allow to companies quickly obtain a certificate of registered VAT identification numbers 
of their business partners, and to enable the tax administration monitoring and controlling the flow of trade within the Community, in order to determine any possible irregularities.

The authority is responsible for maintaining the proper functioning of the system is Central Lisbon's Office, which has direct access to national databases, which is realized through this system. <http://ec.europa.eu/taxation _customs/taxation/vat/traders/vat_number/index_en.htm $>$ [5 May 2013]

\section{CONCLUSION}

Based on the elaboration of theoretical principles, as well as comparative analysis of administrative obligations of VAT taxpayers in Serbia and the European Union, it can be given the following conclusions and make appropriate recommendations.

There are several key areas that are important for the successful fulfillment of administrative obligations of taxpayers, while reducing the compliance costs. The first of these areas are, certainly, thresholds for registration. The size of these thresholds are directly dependent on the number of entities to be included in the system. Setting the threshold too high, as in the case of Serbia, favors small taxpayers, but it also poses a potential threat to the budget, because it raises the question of number of taxpayers who are still in the system, choose to exit the system. It remains unclear why he lifted the threshold for voluntary registration. What we would support is the re-introduction of the threshold, whilst modifying provisions on removal (ex officio) of the taxpayers whose turnover falls below this amount for voluntary registration. Thus, allowing them to have an option of choice possible continuation of the activity in the system, would be a good solution for several reasons. First, the VAT is basically a tax that allows taxpayers to a number of advantages over non-registered or exempt taxpayers. This primarily refers to the possibility of obtaining the input tax credit for the tax paid on the purchase of inputs. For unregistered and exempted taxpayers, there is paradox that they are, in fact, taxed, because they do not pay VAT on the sale of their products, but, at the same time, they do not have the ability to refund of input tax, and thus registered taxpayers bypassed them. The reason for this is the fact that registered taxpayers, if they purchase inputs from exempted taxpayers, do not pay input VAT, but charge VAT on their sales. Second, there are the compliance costs related to the registration. The registration of taxpayers in the tax system is very complex, and the additional problem would be passing the same procedure if a taxpayer is deleted (by law) from the records, and then it later decides to re-register.

However, the European Union has its weaknesses in terms of registration. Although it is much more complex than the Republic of Serbia, there are several forms governing registration of taxpayers for certain types of 
activities, including those that are specific in the EU. The existence of these patterns significantly complicate the situation, the more so that there are separate forms for legal entities with different structure (here mainly the taxpayers who are entrepreneurs and taxpayers who are in his ownership structured as a partnership). In this sense, it would not hurt to consider the introduction of a single form, where specific fields should be marked when it comes to this kind of thing in terms of activity and ownership structure.

Another important area is the control system. Unlike the European Union, which has an electronic system of record- keeping and control is available in any time, 24 hours a day, Serbia still relies on paper records and field control, which requires significant compliance costs. Also, there is a greater likelihood of tax evasion for the reasons above. Therefore it would not hurt to set control system similar to the European Union, but adapted to specific national legislation.

\section{REFERENCES}

Bird, R. M., Gendron, P. P. (2007) The VAT in Developing and Transitional Countries, Cambridge University Press

Council Directive 2006/112/EC of 28 November 2006 on the common system of value added tax

http://www.revenue.ie/en/tax/vat/leaflets/distance-sales-eu.html (Accessed: January 10, 2014.)

http://www.hmrc.gov.uk/manuals/vatposgmanual/vatposg3510.htm (Accessed: January 10, 2014.)

http://ec.europa.eu/taxation_customs/resources/documents/taxation/ vat/traders/vat_community/vat_in_ec_annexi.pdf (Accessed: January 10, 2014.)

http://ec.europa.eu/taxation_customs/taxation/vat/traders/vat_number/\#b ackground (Accessed: January 10, 2014 .)

http://www.karanovic-nikolic.com/2012/10/10/srbijaporezi-biltenoktobar-2012/?lang=sr (Accessed: November 20, 2013.)

http://pdvsavetnik.wordpress.com/2013/07/31/izmene-zakona-o-pdv-u/ (Accessed: November 20, 2013.)

http://www.icarus.rs/pdf/Pravilnik\%20o\%20sadrzini\%20i\%20nacinu\%2 0evidentiranja\%20prometa\%20izdavanjem\%20fiskalnog\%20racuna.pdf (Accessed: November 25, 2013.)

http://www.paragraf.rs/propisi/pravilnik_o_konturi_i_bitmapi_fiskalnog _loga_izgledu_fiskalnih_dokumenata_i_znacenju_pojedinih_podataka_sadrzanih _u_fiskalnim_dokumentima.html (Accessed: November 25, 2013.) 
www.poreskauprava.gov.rs/sr/nerezidenti/pregled-

propisa/pravilnici/127/pravilnik-o-poreskom-identifikacionom-broju.html (Accessed: November 23, 2013.)

http://www.pwc.rs/sr/publications/assets/tax-and-legal-alert/tla-2012/15Izmene-Zakona-o-PDV-Oktobar-2012.pdf (Accessed: November 21, 2013.) 


\title{
Slaven Savić, M. A.
}

Herbos fitofarmacija d.o.o, Novi Sad, Srbija

E-mail: slaven.savic.83@gmail.com

\section{ADMINISTRATIVNE OBVEZE PDV OBVEZNIKA- SRBIJA VERSUS EUROPSKA UNIJA}

\begin{abstract}
Sažetak
Porezna administracija svakog poreznog oblika predstavlja vrlo važno područje njegovog uspješnog funkcioniranja. To se najbolje vidi u primjeru poreza poput PDV-a. Iako je on značajan u poreznom sustavu svake zemlje, jer u velikoj mjeri pridonosi punjenju državnog proračuna, uslijed brojnih specifičnosti njegovog funkcioniranja, zahtjeva adekvatnu poreznu administraciju. Budući da je PDV kompleksan porezni oblik, ukoliko se postave neodgovarajuće zakonske osnove, njegovo funkcioniranje može izazvati visoke administrativne troškove koje snose $i$ država (tj. njezini kontrolni organi) i sami porezni obveznici. Posebna opasnost prijeti od pojave porezne evazije koja, ukoliko se pojavi, dovodi do čitavog niza problema u poreznom sustavu određene države. Ovaj rad osvjetljava razliku u odnosu prema zahtjevima koji su postavljeni pred porezne obveznike u dva potpuno različita porezna sustava. S jedne strane, Republika Srbija, po svojoj veličini $i$ gospodarskom potencijalu, ima relativno malo gospodarstvo, pa je potrebno postaviti takve porezne propise koji će biti dovoljno "jeftini" u smislu ispunjavanja zahtjeva poreznih obveznika, a koji ce osigurati da porezi koje isti uređuju stvore dovoljnu masu fiskalnih prihoda. S druge strane, Europska unija je značajno razvila porezne zakone, koji, $u$ isto vrijeme, postavljaju $i$ komplicirane administrativne zahtjeve. Zbog toga, preporuke za oba područja koja se analiziraju, će ići u smjeru dodatnog usklađivanja i pojednostavljenju propisa, kao i izbjegavanju glomazne i neučinkovite administracije. Konačno, potrebno je uskladiti iste s masom prikupljenih poreznih prihoda.
\end{abstract}

Ključne riječi: porez na dodanu vrijednost, porezna administracija, Srbija, Europska unija

JEL klasifikacija: H20, H25

Sa srpskog na hrvatski standardni jezik prevela: Nikolina Kuraica 